Marquette University

e-Publications@Marquette

Theology Faculty Research and Publications

Theology, Department of

$7-1-2006$

From Faith to the Text and Back Again: Martin Luther on the Trinity in the Old Testament

Mickey Mattox

Marquette University, mickey.mattox@marquette.edu

Published version. Pro Ecclesia, Vol. 15, No 3 (Summer 2006): 281-303. Publisher link. (C) 2006 Center for Catholic and Evangelical Theology. Used with permission. 


\title{
FROM FAITH TO THE TEXT AND BACK AGAIN: MARTIN LUTHER ON THE TRINITY IN THE OLD TESTAMENT
}

\author{
Mickey L. Mattox
}

In the fourth volume of his study of the Christian tradition, Jaroslav Pelikan observed somewhat cryptically that the Reformation doctrine of justification should be understood as a development not only from Augustinian theological anthropology, but from the dogma of the Holy Trinity as well. ${ }^{1}$ That markedly Catholic reading of Reformation theology as a whole stands in rather sharp contrast to the judgment made by the great Adolph von Harnack just a century ago. Having drunk perhaps a bit too deeply from the wells of Ritschlian theology, Harnack labeled Martin Luther's Trinitarian doctrine an "unspeakable confusion." On Harnack's account, Luther's confusion resulted quite naturally from the fact that he did not actually believe in the Trinitarian God of the Catholic tradition. The idea had no place in Luther's system, Harnack argued, and it fit only uncomfortably, if at all, alongside his central concerns. For Harnack, Luther's actual conception of God, as opposed to his occasional tipping of the hat to the

Mickey L. Mattox, Assistant Professor of Historical Theology, Department of Theology, Marquette University, P.O. Box 1881, Milwaukee, WI 53201-1881. E-mail: mickey.mattox@marquette.edu

1. Jaroslav Pelikan, Reformation of Church and Dogma, vol. 4 of The Christian Tradition: A History of the Development of Doctrine (Chicago: University of Chicago Press, 1984), 156-58. For a somewhat fuller development of this point, see his Obedient Rebels: Catholic Substance and Protestant Principle in Luther's Reformation (New York: Harper and Row, 1964), 47-48. For a more traditionally Lutheran angle on the relationship between Luther's doctrine of justification and his doctrine of God, see Paul Althaus, "Gottes Gottheit als Sinn der Rechtfertigungslehre Luthers," Lutherjahrbuch 13 (1931): 1-28. Althaus does not attempt to ground Luther's doctrine of justification in his Trinitarian theology but instead attempts to show that it rests on his prior insistence that the theologian "let God be God"-i.e., that Christians should understand themselves as creatures utterly determined by God's word of grace and promise. 
Trinitarian tradition, had little in common with the "speculations of the Greeks." "Father, Son, and Holy Spirit," he claimed, did not mean to Luther "three Persons existing side by side." Instead, he believed only that the "one God and Father has opened His Fatherly heart to us in Christ and reveals Christ in our hearts by His Spirit." 2 Modalism, Harnack infamously suggested, probably best approximates Luther's view of the "trinity." ${ }^{\text {"3 }}$

Since the nineteenth century, many studies of Luther's thought-even when they have avoided the extremes of Harnack's interpretation-have implied or openly suggested that the Reformer felt little enthusiasm for the Trinitarian theology of the Catholic tradition. ${ }^{4}$ Many more have tended to treat the Trinity as marginal to Luther's thought generally. ${ }^{5}$ Even in Harnack's own day, however, the best Luther scholarship rejected those conclusions. Julius Köstlin, for example, vigorously asserted the orthodoxy of Luther's doctrine of the Trinity, ${ }^{6}$ a judgment that has now been confirmed by a host of studies. ${ }^{7}$ Most observers now recognize that Harnack's reading of Luther revealed far more about Harnack's own commitment to the emerging traditions of liberal Protestantism than it did about Luther's doctrine of God.

2. Adolph von Harnack, History of Dogma, vol. 7, trans. Neil Buchanan (New York: Dover, 1961), 242. Harnack's phraseology is reminiscent of the language of Luther's Large Catechism, a fact that probably rendered his argument plausible in spite of its manifest tendentiousness. He also claims that Luther did not believe Christ to be one divine person, but a man. Contra Harnack, see Edmund Schlink, Theology of the Lutheran Confessions, trans. Paul F. Koehneke and Herbert J. A. Bouman (Philadelphia: Fortress, 1961), 60-66.

3. Harnack, History of Dogma, p. 199. The classical expression of Harnack's own theology and piety is What is Christianity? (Philadelphia: Fortress, 1957).

4. I am by no means the first to complain about this. See, inter alia, Christoph Schwöbel, "The Quest for Communion: Reasons, Reflections, and Recommendations," in The Church as Communion: Lutheran Contributions to Ecclesiology, LWF Documentation No. 41, 1997, ed. Heinrich Holze (Geneva: Lutheran World Federation, 1997), 227-85, esp. 266-68. Commenting on the place accorded the Trinity in the Luther studies of Paul Althaus, Werner Elert, and Gerhard Ebeling, Schwöbel observes: "If we were to rely on these books, we would have to give up looking in Luther's work for a trinitarian theology relevant for ecclesiological reflection on the church as communion" (268). Similar observations may be found in Risto Saarinen's "EastWest Dialogues and the Theology of Communion," also in The Church as Communion, 317-38.

5. While an otherwise insightful study, for example, Hans Schwarz's True Faith in the True God: An Introduction to Luther's Life and Faith, trans. Mark William Worthing (Minneapolis: Augsburg, 1996), scarcely even mentions the place of the Trinity in Luther's theology. Similarly, Paul Althaus blandly observes that Luther "accepted the basic dogmas of the early church on the Trinity and the person of Christ." See The Theology of Martin Luther, trans. Robert C. Schultz (Philadelphia: Fortress, 1966), 7.

6. See Julius Köstlin's The Theology of Luther in Its Historical Development and Inner Harmony, 2nd ed., 2 vols., trans. Charles E. Hay (Philadelphia: Lutheran Publication Society, 1897). To this point: vol. 2, 310-20.

7. See, e.g., the treatments of Luther's doctrine of God in the Theologische Realenzyklopädie (Berlin: Walter de Gruyter, 1991) and in the Evangelisches Kirchenlexikon: Internationale theologische Enzyklopädie (Göttingen: Vandenhoeck \& Ruprecht, 1992). Still helpful on the topic is Regin Prenter's Spiritus Creator: Luther's Concept of the Holy Spirit, trans. John M. Jenson (Philadelphia: Fortress, 1953), esp. 173-84. 
The present essay, then, is not an attempt to vindicate the Catholicity or orthodoxy of Luther's Trinitarian theology. Instead, focusing on the elder Luther, it aims at a better understanding of the interrelationship between Luther's doctrine of God and his interpretation of Holy Scripture. What role did Trinitarian theology play in Luther's scriptural exegesis? How was the doctrine of the Trinity related to Luther's insistence that the words of the biblical text (verba Scripturae sacrae) could only properly be understood when illuminated by the "substance of Holy Scripture" (res Scripturae sacrae) $?^{8}$ The answer, I will argue, lies at least in part in the particulars of Luther's Trinitarian theology - that is, in his understanding of what it means for the Christian to have saving faith in God. Thus, in the first section of what follows I sketch out in brief the results of recent research into Luther's doctrine of the Trinity. In a second section, I offer a close reading of his exposition of the Apostles' Creed as found in the Large Catechism (LC). In a final section, I try to show how Luther employed the knowledge of God the Trinity in his exegesis of the Old Testament. Here I draw attention to Luther's most extended appeal for the Trinitarian interpretation of the Old Testament, found in a treatise somewhat enigmatically entitled "On the Last Words of David" (1543). This treatise makes it clear that the knowledge of God as confessed in the Catholic creeds functions for Luther exegetically as both an irreplaceable starting point and an inescapable conclusion for the authentic Christian reading of Holy Scripture. The elder Luther's insistence on the connections between faith and faithful biblical exposition underscores not only his continuity with the exegesis of patristic and medieval writers, but also-at least as he himself saw the matter-the identity of his faith with that of the "holy fathers."

Of course, it is widely recognized that as a young professor of Bible Martin Luther had positioned himself on the leading edge of sixteenthcentury biblical scholarship, eagerly appropriating, for example, the exegetical tools made available in Erasmus's Novum Instrumentum and Reuchlin's Hebrew grammar. He was fully aware, however, not only of the reforming trajectories inherent in the use of these tools, but also of the critical problems they posed. ${ }^{9}$ In his later years, Luther became markedly

8. See, e.g., Luther's remarks in his exegesis of Gen 4, in D. Martin Luthers Werke: Kritische Gesamtausgabe, ed. J. F. K. Knaake et al. (Weimar: Böhlau, 1883ff), 42: 195 (hereafter cited as WA); Luther's Works, ed. Jaroslav Pelikan and Helmut T. Lehmann (Saint Louis: Concordia; Philadelphia: Fortress Press, 1958ff), 1: 264 (hereafter cited as LW): "And so, if the matter [res] is not understood, it is impossible for the words to be correctly understood either. Although a knowledge of the words [verba] comes first, nevertheless a knowledge of the matter is of greater importance." For an analysis, consult Mickey Leland Mattox, "Defender of the Most Holy Matriarchs": Martin Luther's Interpretation of the Women of Genesis in the Enarrationes in Genesin, 1535-1545 (Leiden: Brill, 2003), 166-68.

9. On this issue, one may consult Helmar Junghans, "Luther als Bibelhumanist," Zeitschrift der Luther-Gesellschaft 53 (1982): 1-9. 
concerned that these presumed advances in biblical studies had destabilized the long-settled results of Christian scriptural interpretation, particularly in the sensitive matter of the relationship between New Testament and Old. Having played a not inconsiderable role in letting this particular critical cat out of the bag, the elder Luther insisted-primarily in opposition to translators and interpreters from the emerging Reformed tradition-that authentic Christian exegesis depends first and always on the authentic knowledge of God.

\section{LUTHER'S CATHOLIC TRINITARIANISM}

Many of the critical questions scholars like Harnack once raised in regard to Luther's Trinitarian theology have been answered simply by paying more careful attention to the historical context and rhetorical thrust of Luther's writings. ${ }^{10}$ In the standard monograph on the topic, for example, Reiner Jansen recognized that, as Harnack had claimed, some Luther texts could be construed either in a modalistic or even in a tritheistic direction. Taking into account their context, however, he denied that Luther himself did so. ${ }^{11}$ Nevertheless, it should be admitted that the young Luther did question some traditional Trinitarian terminology in a way that would have caused understandable consternation. His reticence to lean too heavily on these terms sprang, however, not from doubts about Trinitarian theology itself, but from his recognition of the provisionality and inadequacy of philosophical terms for their divine subject matter.

For example, in the heat of controversy in 1521 Luther argued that the faithful theologian could not be compelled to use nonbiblical language, including the Nicene homoousios. In "Against Latomus," he insisted that one may hold to the reality to which the Fathers referred (as, for example, the New Testament writers apparently did) even without using the particular term on which the Fathers nevertheless rightly insisted. ${ }^{12}$ His point

10. Some of the relevant texts were assembled and translated into modern German in Emanuel Hirsch's Hilfsbuch zum Studium der Dogmatik (Berlin: de Gruyter, 1964), 16-22.

11. See Reiner Jansen, Studien zu Luthers Trinitätslehre (Bern and Frankfurt/M.: Herbert Lang and Peter Lang, 1976).

12. WA 7: 117; LW 32: 244: "one must be indulgent to the fathers for having once used a wond which is not found in Scripture. Otherwise, if you were to adopt this precedent, it would be permissible to translate all of Scripture into other words, just as the sophists do. Even if my soul hated this word, homoousion, and I refused to use it, still I would not be a heretic. For who compels me to use the word, providing I hold to the fact defined by the council on the basis of Scripture?" 
was that the church's admittedly correct usage of even such a venerable term as the homoousios does not set a general precedent that gives the theologian license to substitute philosophical terms for the biblical language. Nevertheless-and this point bears repeating-even as a young and somewhat critical theologian, Martin Luther thought the Nicene Fathers had acted rightly - and fully in accordance with Scripture-when they adopted the homoousios. ${ }^{13}$

Similarly, Luther at times spoke critically of the German term Dreifaltigkeit (literally, "three-foldedness"), which was traditionally used to translate the Latin trinitas, primarily on grounds that no human language is adequate to the task of expressing the "unspeakable" mystery of the Christian doctrine of God. According to Bernhard Lohse, Luther's occasional criticism of speculative philosophical approaches to the Trinitysuch as he sometimes seems to have detected embedded in the Dreifaltigkeit-can be explained by his determination that talk about God should be concrete and direct, as well as his recognition that a metaphor like "three-foldedness" has its limits. All our speech about God has as its referent the One who is Lord not only over the cosmos and its history, but over our own lives and our philosophical concepts as well. ${ }^{14}$ These qualifications and reservations notwithstanding, we now also know that the elder Luther developed a keen appreciation for the necessity of nonbiblical Trinitarian terminology as shorthand for summarizing the biblical witness, particularly in the face of persistent attacks upon the faith. ${ }^{15}$

Recent research has also made it clear that Luther appropriated and relied heavily on the conceptual tools developed by medieval theologians in the construction of his own Trinitarian theology. From his

13. On this point, see Leif Grane, The Augsburg Confession: A Commentary, trans. John $\mathrm{H}$. Rasmussen (Minneapolis: Augsburg, 1987), 33-39. For Luther's later defense of the use of nonbiblical language in theology, see his "Von den Konziliis und Kirchen," WA 50: esp. 572-73: "It is certainly true that one should teach nothing outside of Scripture pertaining to divine matters, as St. Hilary writes in On the Trinity, Book I, which means only that one should teach nothing that is at variance with Scripture. But that one should not use more or other words than those contained in Scripture-this cannot be adhered to, especially in a controversy and when heretics want to falsify things with trickery and distort the words of Scripture. It thus became necessary to condense the meaning of Scripture, comprised of so many passages, into a short and comprehensive word, and to ask whether they regarded Christ as homoousios, which was the meaning of all the words of Scripture that they had distorted with false interpretations among their own people, but had freely confessed before the emperor and the council."

14. See Lohse's Luthers Theologie in ihrer historischen Entwicklung und in ihrem systematischen Zusammenhang (Göttingen: Vandenheock \& Ruprecht, 1995), 223-27, esp. 226.

15. On this issue, see Christoph Markschies, "Luther und die altkirchliche Trinitätstheologie," in Luther-zwischen den Zeiten: Eine Jenaer Ringvorlesung, ed. Christoph Markschies and Michael Trowitzsch (Tübingen: Mohr Siebeck, 1999), 37-85, esp. 38-44, 56-59. 
earliest marginal annotations on Lombard's Sentences to the disputations he prepared for his students many years later, Luther made constructive use of the Scholastic theology of the Holy Trinity. In an examination of theses Luther prepared for a promotional disputation for Petrus Hegemon in 1545, Simo Knuuttila and Risto Saarinen have shown how much Luther relied on the conceptual tools developed in medieval Scholasticism. ${ }^{16}$ Important as it is to recognize Luther's concern for the Trinitarian faith among his academic peers and students, however, it would be a mistake to reduce the Trinity to an academic question in Luther's theology. Traversing the boundaries between the disputation, the sermon, and the hymn, Christine Helmer has explored some of the further reaches of Luther's Trinitarian understanding of God, not only in the disciplina arcana of the academic theologian, but in the faith proclaimed and sung in the church's assembly as well.17

Of course, from Luther's perspective, properly trained pastors were essential to the perpetuation of the Trinitarian faith in the church. Even a short quotation from such an unexpected source as the Enarrationes on Genesis (1535-1545) can succinctly indicate the extent to which in the classroom, too, he attempted to school his students in solid Trinitarian theology. Professor Luther's insistence that there can be no division between the subjective apprehension of God-what God is for us-and what God is an sich marks his theology as deeply Athanasian and Catholic. ${ }^{18}$ Lecturing in 1535, for example, Luther modeled for his students the Christian exposition of the first-person plural verb form in Gen 1:26-faciamus hominem.

Therefore here [i.e., in Gen 1:26] the Trinity is clearly signified, that in the one divine essence there are three persons, Father, Son and Holy Spirit; thus not even with regard to activity [of creation] is God separated, for all three persons here agree together and say "let us make." The Father does not make any other man than the Son, nor the Son than the Holy Spirit, but the Father, Son and Holy Spirit, one and the same

16. "Innertrinitarische Theologie in der Scholastik und bei Luther," in Caritas Dei: Beiträge zum Verständnis Luthers und der gegenwärtige Ökumene, ed. Oswald Bayer, Robert W. Jenson, and Simo Knuuttila (Helsinki: Luther-Agricola-Gesellschaft, 1997), 243-64. Abundant further confirmation of Luther's reliance on scholastic theology may be found in Pekka Kärkkäinen, Luthers trinitarische Theologie des Heiligen Geistes (Mainz: Philipp von Zabern, 2005).

17. See Christine Helmer, The Trinity and Martin Luther: A Study on the Relationship between Genre, Language, and the Trinity in Luther's Works (1523-1546) (Mainz: Philipp von Zabern, 2005).

18. On the connections between Nicene Trinitarianism and early Catholic soteriology, one may consult Thomas Torrance, The Trinitarian Faith: The Evangelical Faith of the Ancient Catholic Church (Edinburgh: T. \& T. Clark, 1988). 
God, is the author and creator of the same work. Thus neither in this way can God be separated as a thing present to the mind [obiective]. For God the Father is not known, except in the Son and through the Holy Spirit. Therefore just as with regard to activity [i.e., Creation] so also as a thing present to the mind God is one, who nevertheless within himself substantively or essentially is Father, Son, Holy Spirit, three distinct persons in one divinity. ${ }^{19}$

For Luther, God the Creator is a Trinity of divine persons whose works are, as Augustine had famously put it, indivisible..$^{20}$ Moreover, this Creator is also the God known in Christian faith. The God who acts in creation, the God who is, and the God known in Christian faith-this is the one God. The revelation of God the Father in the Son through the Holy Spirit is therefore a revelation of God as God is. Trinitarian theology therefore means nothing less than the mystery of God made known.

Teaching this mystery, Luther developed his own distinctive Germanlanguage terminology, using the terms von aussen and von innen to denote

19. WA 42: 143-44: "Quare est hic certo significata Trinitas, quod in una essentia divina sunt tres personae, Pater, Filius et Spiritus sanctus, ita ut ne active quidem Deus separetur, quia omnes tres personae hic concurrunt et dicunt, 'faciamus'. Nec Pater facit alium hominem, quam Filius, nec Filius alium quam Spiritus sanctus, sed Pater, Filius, Spiritus sanctus, unus et idem Deus, autor et creator est eiusdem operis. Ad hunc modum neque obiective Deus potest separari. Neque enim Pater cognoscitur, nisi in Filio, et per Spiritum sanctum. Quare sicut active ita quoque obiective unus Deus est, qui tamen intra se substantive seu essentialiter est Pater, Filius, Spiritus sanctus, tres distinctae personae in [12] una divinitate." Translation mine; emphasis added. Cf. LW 1: 58.

I understand the Latin "active" here as a reference to God's action in creation. In sixteenthcentury parlance, the term "obiective" denotes an object (i.e., a thing concerning which one may predicate) present to the mind; as such, it could be understood as a "subjective" reality. Thus, the term might be rendered, as is the case in the LW, with the English term "subjective." However, to do so without further explanation severs the connection between the object present to the mind and the object as such, or, in this case, between the God who is present to Christian understanding and the God who is "substantive seu essentialiter." In medieval terms, this latter phrase again refers to God as "obiectum," but this time as an extramental reality whose existence clearly does not depend on the subjective presentation of this object to the mind for the purpose of understanding. On this philosophical issue and the medieval terminology, see Léon Baudry, Lexique Philosophique de Guillaume D'Ockham (Paris: P. Lethielleux, 1958), 182-84. See also Rudolf Eucken, Geschichte der philosophischen Terminologie (Hildesheim: Georg Olms, 1879), 68. I thank Richard Muller for assistance with this problem.

20. Luther explicitly agrees with Peter Lombard in rejecting the notion that the essence of God constitutes a fourth divine something, the co-called "quaternity." On this point, as well as for a helpful analysis of the elder Luther's appropriation of traditional scholastic Trinitarian terminology, see Graham White, Luther as Nominalist: A Study of the Logical Methods Used in Martin Luther's Disputations in the Light of Their Medieval Background (Helsinki: LutherAgricola Society, 1994), 181-230. See also Risto Saarinen, "Die moderne Theologie und das pneumatologische Defizit," in Der Heilige Geist, ed. Joachim Heubach, Veröffentlichungen der Luther-Akademie Ratzeburg (Erlangen: Martin-Luther-Verlag 1996), 245-63. 
what are commonly referred to today as the economic and the essential Trinity. ${ }^{21}$ Preaching on John 1, for example, in 1541, Luther said:

We should not consider God only from the outside, in his works; to the contrary, he also wants to be known as he is inwardly; internally he is one essence and three Persons, the Father, Son, Holy Spirit, and not three gods; thus we pray only to one God. How can that be? It is ineffable; in their joy the beloved angels themselves cannot sufficiently rejoice at this; to us however it is grasped and proclaimed in the Word.22

This twofold knowledge of the "outer" and "inner" God in turn makes possible the right praise of God. While for Luther the knowledge of God is not to be understood in such a strongly ontic sense as to make it dependent on a prior philosophy of being, it is nevertheless knowledge of God as God "inwardly" is. ${ }^{23}$ And this knowledge of God introduces one into a never-ending cycle that moves from the gracious actions of God to a graced humanity and back to God again. Having received the grace and gifts and right knowledge of God, the Christian returns thanks and praise to God. Thus, the knowledge of God on Luther's account is properly doxological.

Some scholars have discerned in texts like this one a Trinitarian theology that tends toward Byzantine "personalism" rather than the so-called Western "monism." ${ }^{24}$ Without passing judgment upon either that claim or the characterization of Western versus wastern theology that it presupposes, ${ }^{25}$ suffice it for the present to note that for Luther the doctrine of the

21. The distinction between the "essential" and "economic" Trinity is not Luther's own. Wolfhart Pannenberg credits J. Urlsperger (1728-1806) with having introduced this distinction into Western theology. See Pannenberg, Systematic Theology, vol. 1, trans. Geoffrey Bromiley (Grand Rapids: Eerdmans, 1991), 291, n. 111.

22. WA 49: 238-39: "Wir sollen aber Gott nicht allein ansehen von aussen in seinen wercken, sondern er wil auch erkant sein, was er inwerts ist, inwendig ist ein einig wesen und drey Personen, der Vater, Son, heiliger Geist, nicht drey Goetter, Beten derhalben nur ein Gott an. Wie gehets denn zu? unaussprechlich ists, die lieben Engel koennen sich nicht gnugsam darueber verwundern fur freuden, uns wirds ins Wort gefasset und furgeprediget." My translation. For the text in modern German, see Hirsch, Hilfsbuch, 21-22.

23. For the Trinitarian ontology of the young Luther, one may consult the interesting if inconclusive study of Tuomo Mannermaa, "Hat Luther eine trinitarische Ontologie?" in Luther und Ontologie: Das Sein Christi im Glauben als strukturierendes Prinzip der Theologie Luthers, Schriften der Luther-Agricola-Gesellschaft 31/Veröffentlichungen der Luther-Akademie Ratzeburg 21 (Helsinki and Erlangen, 1993), 9-27.

24. See Albrecht Peters, "Die Trinitätslehre in der reformatorischen Christenheit," Theologische Literaturzeitung 94 (1969): 561-70. Note well the near-absence of explicit mention of the immanent Trinity in the LC. On this problem, see Jansen, Luthers Trinitätslehre, 74-86.

25. Augustine is the alleged source for a distinctive Western Trinitarian theology that "begins" with the divine unity, as opposed to the economic approach characteristic of the Christian East. The origins of this construct have been thoroughly explored and convincingly critiqued in M. R. Barnes, "De Régnon Reconsidered," Augustinian Studies 26 (1995): 51-79; Barnes, "Augustine in Contemporary Theology," Theological Studies 45 (1995): 237-50. For a 
Trinity is grounded in God's creative, redemptive, and sanctifying work in human history. Once again, then, the knowledge of God is Trinitarian with respect to its ontological ground, to the structure of God's self-revelation in history, and to the reality of Christian experience.

\section{THE LARGE CATECHISM}

The distinctions and connections between the objective ground of the doctrine of the Trinity and the subjective experience of the Triune God in Luther's understanding of faith are nowhere made clearer than in the LC, particularly in his exposition of the Apostles' Creed. ${ }^{26}$ This exposition follows a surprisingly lengthy treatment of the Ten Commandments, ${ }^{27}$ so that the creed functions not only to identify the Christian God, but also, in distinctively Lutheran fashion, as the word of gospel that answers the Ten Commandments in their function as divine law. ${ }^{28}$ Each of these commandments "constantly accuses us," 29 Luther explains; but the creed sets forth "all that we must expect and receive from God." ${ }^{30}$ Indeed, the reality of God as known and confessed in the creed shows where strength for a Christian existence shaped by the imperatives of the Ten Commandments may be found. Faith enables the baptized believer to find even within the Ten Commandments a word of grace and promise-that is, "I am the Lord, your God" - and to answer that word with an emphatic "I believe." ${ }^{31}$ Enlightened by the right knowledge of God and enkindled by the flame of love for God made possible by the gospel, the Christian properly

reading of Augustine's theology that challenges the view that he "begins" with divine unity, see Lewis Ayres, "'Remember That You Are Catholic' (serm. 52.2): Augustine on the Unity of the Triune God," Journal of Early Christian Studies 8 (2000): 29-82.

26. I cite the original German of the LC from Die Bekenntnisschriften der evangelischlutherischen Kirche, 6th ed. (Göttingen: Vandenhoeck \& Ruprecht, 1967), abbreviated BSLK. ET The Book of Concord: The Confessions of the Evangelical Lutheran Church, ed. Robert Kolb and Timothy J. Wengert (Minneapolis: Fortress, 2000), abbreviated BC.

27. On Luther's nearly overwhelming concentration on the Ten Commandments in the LC, see George Lindbeck, "Martin Luther and the Rabbinic Mind," in Understanding the Rabbinic Mind: Essays on the Hermeneutic of Max Kadushin, ed. Peter Ochs (Scholars Press, 1990), $141-64$.

28. Note well, however, Lindbeck's caution that Luther does not always treat the Ten Commandments as Law. Lindbeck, "Martin Luther," 149-52.

29. BSLK, 639; BC, 427.

30. BSLK, 646; BC, 431.

31. On Luther's interpretation of the First Commandment, see Althaus, Theology of Martin Luther, 130-32. As Althaus points out, Luther takes this commandment as a word of gospel given in the form of a command. In the LC, Luther even goes so far as to put words into God's mouth, informing the catechist exactly what God requires of us here: "See to it that you let me alone be your God, and never search for another." BSLK, 647; BC, 387. 
discerns in the Ten Commandments both the rudimentary principles of the ideal social order and a guide for living the godly life. The wisdom of the creed, however, takes us far beyond the Ten Commandments, for "it teaches us to know God wholly and completely." ${ }^{22}$ As Luther understands it, the creedal identification of the Triune God is in toto gospel, a word of grace that tells us who God is and what God has done for us.

\section{First Article}

In his interpretation of the first article, Luther asserts that the eyes of faith enable Christians to perceive in the creation the paternal benevolence of God the Father. By faith Christians recognize that all receive with respect to earthly blessings-"good government, peace, and security"-proceeds from the love of God. For Luther this means that the first article is a Christian confession of faith in God as Creator, one that serves to correct the faulty self-assessment that results from sin, the self-deceptive sense of autonomy the human being has apart from God. To know God as Creator means, conversely, to know the self as creature, as one whose limits have been determined by God. Luther writes: "Thus we learn from this article that none of us has life- or anything else that has been mentioned here or can be mentioned-from ourselves, nor can we by ourselves preserve any of them, however small and unimportant." 33 The recognition that God alone is the Creator means the end of every form of autonomous human self-assertion over against God. For Luther, as Althaus reminds us, God "creates out of nothing and even out of its opposite." ${ }^{134} \mathrm{God}$ as God has the power not only to call the creation into being out of nothing, but also to create sons and daughters of God out of the raw material, so to speak, of sinful humanity. In this way God demonstrates that in the matter of redemption as well as that of creation he is the Creator on whom the human creature is in every way dependent. Luther's insistence that in this matter we let God alone be God thus stands as the negation of every form of idolatry, including the idolatry of a righteousness based on human works.

To know God as Father, as Luther sees the matter, is to know "pure love and goodness," the unmerited grace of God's provision for every aspect of human life, now and in eternity. In the rich goodness of the created order, moreover, the Christian is enabled truly to see that love and goodness. Knowing God as Creator means perceiving God's "fatherly heart [väterlich Herz] and his boundless love toward us." ${ }^{35}$ Thus, according to Luther, "our hearts will be warmed and kindled with gratitude to God

32. BSLK, 646: "ihn ganz und gar erkennen lehret." Cf. BC, 431.

33. BSLK, 648; BC, 433.

34. Theology of Martin Luther, 127.

35. BSLK, 650; BC, 433. 
and a desire to use all these blessings to his glory and praise. ... For here we see how the Father has given himself to us."36 As Albrecht Peters notes, Luther's point here is precisely that in the Son and through the Holy Spirit, the Father not only discloses but also gives himself to us as a gift. ${ }^{37}$ Knowing the God and Father revealed and confessed in the creed therefore means much more than merely intellectually apprehending by means of the created order that there is a benevolent Creator. The perception of the "fatherly heart" of the Triune God returns Christians to God with praise and then sends them out into the world filled with love for the creation and a determination that it, too, should reflect honor, praise, and glory to its Maker.

\section{Second Article}

From a theologian who could at times reduce the entire task of the biblical exegete to finding in the text was Christum treibet ("whatever promotes Christ"), ${ }^{38}$ one would naturally expect an expansive treatment of the second article. For that reason, what is most striking about Luther's explanation is its brevity. To know God the Son, Luther writes, is "to get to know the second person of the Godhead" (die andere Person der Gottheit), the "true Son of God" who has become "Lord" through his victory over sin, the devil, death, and evil. ${ }^{39}$ "The only and eternal Son of God" (einige und ewige Gottessohn), Luther remarks, has graciously become our Lord through his work as Redeemer. ${ }^{40}$ The emphasis here is subjective, in the sense that Luther portrays the Son establishing himself as our Redeemer by means of his saving work, focusing on its sheer gratuity and on the utter hopelessness of humanity apart from that work. At the same time, there is a dialectical quality to Luther's exposition, for, as he puts it, the redeeming work of the Lord Christ means that he "has bought us back from the devil to God, from death to life, from sin to righteousness." ${ }^{11}$ As Heiko A. Oberman reminded us, the interpreter of Luther must remain ever mindful that for Luther the Christian's struggle for faith takes place not primarily in the "Protestant citadel" of the conscience, but in the titanic and very much this-worldly battle between God and the devil. ${ }^{42}$

36. BSLK, 650 . I have altered the translation slightly from what one finds at BC, 433 .

37. See his "Verborgener Gott-Dreieiniger Gott: Beobachtungen und Überlegungen zum Gottesverständnis Martin Luthers," in Martin Luther "Reformator und Vater im Glauben," ed. Peter Manns (Wiesbaden: Franz Steiner Verlag, 1985), 74-105; here 83.

38. "Vorrhede auff die Episteln Sanct Jacobi unnd Judas," 1522. WADB 7: 384.

39. BSLK, 651; BC, 434.

40. BSLK, 651; BC, 434.

41. BSLK, 652; BC, 434.

42. Heiko A. Oberman, Luther: Man between God and the Devil (New Haven: Yale University Press, 1989), 155. 
The significance of Christology in the context of Luther's Trinitarian theological reflection is of course greater than might be inferred on the basis of the short exposition found here. As Simo Peura has observed, the starting place for Luther's Trinitarian theology is the work and person of the Redeemer. Directing the reader's attention to Luther's 1538 treatise tellingly entitled "Die drei Symbola oder Bekenntnis des Glaubens Christi," Peura remarks that the knowledge of God for Luther is grounded first, last, and always in the humanity of Christ. This is not to say, however, that God the Father or God the Holy Spirit are not to be known, as if they could somehow be rendered superfluous by Luther's christocentrism. To the contrary, it is the Son who in his incarnate humanity opens the way to knowing God-Father, Son, and Spirit-in a saving way. ${ }^{43}$

\section{Third Article}

Nevertheless, the bulk of Luther's exposition of the Apostles' Creed is directed to the third article: "Sanctification" (die Heiligung). The ministry of the Holy Spirit is the starting point of Christian faith and life, for the Spirit brings the Christian to Christ and through Christ reveals the love of the Father. Moreover, the work of the Spirit is the ground and origin of the church into which the Christian has been called and gathered. ${ }^{44}$ The Holy Spirit effects the communio sanctorum by leading sinners to Christ and by offering and applying to them the benefits of the redeeming work of the Son. In a certain sense, then, sanctification means for Luther simply being incorporated into Christ, our righteousness. But that incorporation is itself impossible without the ministry of the Spirit in the church. No Spirit, no church, no Christ, and, therefore, no salvation. Thus, one could as well say for Luther as for St. Cyprian, extra ecclesiam nulla salus. ${ }^{45}$ The church is "the mother that begets and bears every Christian through the Word."46 Luther's pneumatology here also has an eschatological orientation, for it is the Spirit who will raise the faithful and bring them to eternal life. With this end in view, the Spirit works in the present to make the faithful "pure saints under one Head, Christ," and the Spirit does so by applying the Gospel in all its aspects. ${ }^{47}$ What makes the church itself indispensable for

43. Simo Peura, "Das Sich-Geben Gottes: Die Trinitätslehre als integrales Problem der Theologie Martin Luthers," in Luther und die trinitarische Tradition: Ökumenische und philosophische Perspektiven, Veröffentlichungen der Luther-Akademie e.V. Ratzeburg, vol. 23, ed. Joachim Heubach (Erlangen: Martin-Luther-Verlag, 1994), 131-46.

44. On the Spirit's work in calling and gathering the church in Luther's catechesis, one may consult Jared Wicks, SJ, "Holy Spirit-Church-Sanctification: Insights from Luther's Instructions on the Faith," Pro Ecclesia 2 (1993): 150-72.

45. BSLK, 658; BC, 438.

46. BSLK, 655; BC, 436.

47. BSLK, 657; BC, 437. 
salvation is precisely the Spirit's presence, for it is within the church that the Spirit unites believers "in one faith, mind and understanding." 48

To know God, then, is certainly, as Philip Melanchthon famously put it, to know God's benefits, both the paternal ones revealed in God's activity in creation as well as the treasures of redemption effected by Christ. ${ }^{49}$ But to know God either as benevolent Father or as redeeming Son requires that one be brought ever and again into the holy Christian church by the ministry of the Spirit, "him who daily brings us into this community through the Word, and imparts, increases, and strengthens faith through the same Word and the forgiveness of sins. ${ }^{150}$ In Luther's understanding, the ministry of the Spirit leans eschatologically forward, not in such a way as to negate either God's work of creation or that of redemption, but instead to bring those works to their completion and fulfillment. The works of God in creation, redemption, and sanctification are thus directed alike toward an ultimate fulfillment in which each has reached its final end. "For creation is now behind us, and redemption has also taken place, but the Holy Spirit continues his work without ceasing until the Last Day." ${ }^{\prime 51}$ As the Spirit reveals the grace and favor of the Son, so also the Son brings us to the Father who reveals to us the "most profound depths of his fatherly heart, his sheer, unutterable love." 52 Viewed from the standpoint of Christian experience, the knowledge of God given in the symbol proceeds in the Spirit, through the Son, and to the Father. Here living faith in fact lays hold of God, for "in the Creed you have the entire essence, will, and work of God."53

This brief perusal of the LC shows that the Trinitarian faith of the Catholic tradition means much more to Luther than merely a traditional teaching that he could affirm. Indeed, if the Hauptartikel of justification means justification by faith, then faith itself means much more than simply "to assent to the promise of God, in which forgiveness of sins and justification are bestowed freely on account of Christ." ${ }^{14}$ For Luther, faith in God as given to the Christian through the means of grace consists of nothing less than knowledge of the God who is-and very much of God as God is: Father, Son, Holy Spirit.

48. BSLK, 657; BC, 437.

49. The phrase is found in the first edition of his Loci Communes Theologici. ET in Melanchthon and Bucer, ed. Wilhelm Pauck (Philadelphia: Westminster, 1969), 21.

50. BSLK, 660; BC, 439.

51. BSLK, 659-60; BC, 439.

52. BSLK, 660; BC, 439. The German text reads: "Denn da hat er selbs offenbaret und aufgetan den tiefsten Abgrund seines väterlichen Herzens und eitel unaussprechlicher Liebe in allen dreien Artikeln."

53. BSLK, 660; BC, 439. German: "Siehe, da hast Du das ganze göttliche Wesen, Willen und Werk."

54. This is the definition of saving faith as found in Philip Melanchthon's Apology of the Augsburg Confession. BC, 128. These two understandings of saving faith are in my view distinct but compatible. 


\section{III. “ON THE LAST WORDS OF DAVID” (1543)}

As noted above, Luther was convinced that the knowledge of God given in authentic Christian faith could not be bracketed out of properly Christian biblical study, reflection, and exegesis: The res Scripturae sacrae holds the key to the verba Scripturae sacrae. The strength of this conviction seems to have grown over the course of Luther's career, particularly after he had observed some of the exegetical trajectories emerging among the South German and Swiss Reformers. ${ }^{55}$ In 1543, sensing acutely the need for a programmatic statement on the Christian exegesis of the Old Testament, Luther turned his attention to a text very few today, or even in his own day, would have chosen as the basis for a defense of the Trinitarian exegesis of Scripture. Seasoned by more than three decades in the classroom, most of it teaching Old Testament, Luther selected a text he thought had been overlooked, one whose rich potential for urging the Catholic doctrines of God and Christ had been insufficiently recognized. ${ }^{56}$ Here, in Luther's own translation, is 2 Sam 23:1-3:

These are the last words of David. The oracle of David, the son of Jesse. The oracle of the man who is assured of the Messiah of the God of Jacob, the sweet psalmist of Israel. "The Spirit of the Lord has spoken by me, His Word is upon my tongue. The God of Israel has talked to me, the Rock of Israel has spoken, He who rules justly over men, He who rules in the fear of God."57

Announced at the end of "Vom Schem Hamphoras und vom Geschlecht Christi" (also written in 1543), "On the Last Words of David" contained a number of unflattering references to the Jews and some heavy-handed arguments against their exegesis. Thus, the treatise has long been classed among the elder Reformer's notorious anti-Jewish writings. There is no question that Luther wished in the most emphatic terms to reject Jewish readings of important Old Testament texts, much as he had recently insisted in his regrettable treatise "Against the Jews and Their Lies" (1542). Nevertheless, "On the Last Words of David" did not at all take the form of an extended argument with the Jews. Instead, it offered one example after

55. In the Tischreden, Luther seems to indicate an awareness of the Dialogi de Trinitate (1532) of Michael Servetus (Nr. 237; WATR 99: 18-21). According to Martin Brecht, in the 1540s Luther was concerned to defend the Trinitarian dogma against both Servetus and John Campanus. See vol. 3 of his massive biography, Martin Luther: The Preseroation of the Church 1532-1546, trans. James L. Schaaf (Minneapolis: Fortress, 1993), 133.

56. For an intriguing reading of Luther's interpretation that stresses its speculative elements, see Christine Helmer, "Luther's Trinitarian Hermeneutic and the Old Testament," Modern Theology 18 (2002): 49-73.

57. I have slightly altered here the LW translation. See WA 54: 16-100; LW 15: 265-352. 
another of how to discern the authentic grammatical and theological meaning of the Old Testament as Luther understood it. In short, it modeled the way Luther believed Christian exegetes informed by the latest developments in biblical studies ought to read the text.

\section{Luther among His Predecessors and Peers}

Before turning attention to Luther's treatise, it is instructive to cast a brief backward glance at premodern Christian interpretation of this text. Did Luther borrow from the exegetical tradition in his exegesis of 2 Sam 23? So far as I have found, none of the Church Fathers had attempted to read this text in such an expansively Trinitarian way as Luther. Of course, many of the biblical intertexts on which he relied to support and develop his position had long been read as supporting the Trinitarian faith. Second Samuel 7, for example, which recounted at length the divine promise of a Messiah, had been mentioned prominently in Augustine's De Civitate Dei (XVII.8-10). Few among the Church Fathers seem to have turned, however, to 2 Sam 23, and the situation was much the same among the medievals. Thus, the compilers of the Glossa Ordinaria left the text almost entirely uncommented, noting dryly that it was the last "song of David" and observing that the mention of the sunrise in verse 5 prefigured Christ's rising from the dead. ${ }^{58}$ Nicholas of Lyra, whose exegesis we can reasonably expect Luther to have consulted, discerned Christological resonances in this text. ${ }^{59}$ But instead of following them up, he digressed into a brief discussion of grace, observing somewhat laconically that the promise of a Messiah through David's posterity was given on account of God's liberality, not human merit..$^{60}$ Alone among the medievals, so far as I have found, the "Ecstatic Doctor," Denis the Carthusian, found here at least an oblique reference to the Trinity. ${ }^{61}$ Mention of the "Spirit" and the "Lord" in such

58. Biblia Latina cum Glossa Ordinaria, vol. 2 (Strassburg: Adolph Rusch, 1480/81; Facsimile reprint edition Brepols-Turnhout, 1992), 84, interlinear comment on 2 Sam 23:1. Hugh of St. Cher also little explored any theological implications in this text. See Hugonis de Sancto Charo Primi Cardinalis Ordinis Praedicatorum, Tomus Primus (Venetiis, apud Nicolaum Pezzana, 1732), 262r.

59. Note Luther's own remarks confirming his consultation of Lyra, WA 54 : 25 ff.; LW 15: 336. I cite Lyra from the Biblia Sacra cum postilla Nicolai de Lyra (Venice: Renner of Heilbrunn, 1482). Here, page ffv, comment " $h$ " and " 1 ," on verse 1 . The Latin text is a bit awkward to bring into English: "dixit vir cui constitutum est de christo Dei Iacob." For Luther's own remarks on this translation difficulty, see WA 54: 32, 15 ff.; LW 15: 272.

60. Lyra, $\mathrm{ff}^{\mathrm{v}}$, comment " $\mathrm{x}$," on verse 4.

61. Doctoris Ecstatici D. Dionysii Cartusiani Opera Omnia, Tomus III: In Josue, Judices, Ruth, I-III Regum (Monstrolii: 1897), 562: "Facta est revelatio atque promissio de incarnatione, adventu et mysteriis Messiae, Salvatoris mundi, qui est Christus Dei, unctus a Deo Patre omni charismate Spiritus Sancti plenissime, juxta illud in Psalmo." Denis cites Ps 44:8 and Isa 61:1 in support of his point. 
close proximity brought to Denis's mind one of the central principles of classical Trinitarian theology, that is, that the works of the Trinity toward the outside are indivisible. Although he did not spell out the significance of that principle for understanding the biblical text, he at least implied that where the Spirit and the Word were active, there all three persons could and should be found.62

Luther seems to have been well aware of the dimly recognized but as yet unexplored Christological and Trinitarian potential of this text in the antecedent tradition. Indeed, he said in several places that he knew that his "new" grammatical interpretation went beyond the interpretations of the "holy fathers" and the medievals. ${ }^{63}$ Here, then, was the point of focusing attention on this presumably overlooked text, namely, to show how the sixteenth-century revolution in Hebrew studies could be used to buttress the properly Christian reading of the Bible. ${ }^{64}$ But in order to do so, Luther believed he had to refute the "judaizing" interpretations he saw developing among Christian expositors. ${ }^{65}$ Finding Moses "to be a Christian," Luther explicitly lumped together with the Jews those Christian Hebraists who failed sufficiently to factor Christian truth into their interpretation: "All else, whatever Jews, Hebraists, and anybody else may babble against this to make it agree with their stippled, tormented, and coerced grammar, we must certainly consider sheer lies."66 These allegedly false interpreters comprise those many "wiseacres [kluegel] who claim a mas-

62. Doctoris Ecstatici, 562: "Spiritus Domini, videlicet Spiritus Sanctus, locutus est per me, tanquam per organum animatum et intellectuale, quoniam ex divina revelatione pronuntiavi Christi mysteria, et alia multa future ac divina praeconia. . . Et sermo ejus per linguam meam, prolatus est, ita quod verba mea sunt sermo ipsius, cujus directione locutus sum, et qui specialem gratiam componendi psalmos, dulciterque psallendi praestitit mihi, ut dicere queam: Dominus dedit mihi linguam eruditam. Denique Sermo Dei increatus, videlicet Verbum Patris aeternum, per os et linguam David locutus est. Nam opera superbeatissimae Trinitatis sunt indivisa. De quo sermone ad Hebraeos asseritur: Vivus est sermo Dei et efficax."

63. WA 54: 45, 2-3; LW 15: 287. "Wie gehets zu, das wedeer die heiligen Veter, noch kein ander Lerer, solchs gesehen oder jemals gerueret haben, Und jr newen Jungen Ebresiten habts nu erst ersehen?"

64. For a critical assessment of the use of Hebrew studies in support of Christian exegesis in Luther's Wittenberg, see Jerome Friedman, "Protestants, Jews, and Jewish Sources," in Piety, Politics, and Ethics: Reformation Studies in Honor of George Wolfgang Forell, ed. Carter Lindberg (Kirksville, MO: Sixteenth Century Journal Publishers, 1984), 139-56. Friedman is particularly disparaging of the work of Luther's colleague and former student, Johannes Forster, whose Dictionarium Hebraicum Novum attempted to read Christology into the grammar of the Old Testament.

65. On Luther's concern with "judaizing" exegesis, note the helpful work of Stephen Burnett, "The Significance of the Biblical Languages at the University of Wittenberg" (Heidelberg: Ninth International Congress for Luther Research, 1997). This debate is reflected later in the argument between Giles Hunnius and David Paraeus over John Calvin's exegesis. For further detail, see David C. Steinmetz, "The Judaizing Calvin," in Die Patristik in der Bibelexegese des 16. Jahrhunderts, ed. David C. Steinmetz and Robert Kolb (Wiesbaden: Harrassowitz, 1999), 135-45.

66. WA 54: 55, 4; LW 15: 299. Luther's reference is to John 5:46: "Moses wrote of me." 
tery of the Hebrew tongue," 67 and they include in their number "both Jews and Hebraists." 68 Indeed, the prospect of the widespread Christian adoption of this new exegesis troubled Luther so much that he thought it would be better if the church had only Jerome's Vulgate than to endure the confusion caused by numerous, substantially different "grammatical" readings of the Hebrew text. ${ }^{69}$ Instead of simply giving up the game and returning to the time-honored text, however, Luther argued for a more authentically Christian translation and interpretation of the text. "We Christians," he claimed, "have the meaning and import [synn und verstand] of the Bible because we have the New Testament, that is, Jesus Christ."70

Implicitly recognizing that one might more reasonably expect a Trinitarian reading of the Old Testament from a Christian than from a Jew, Luther aimed his criticisms directly at "the old and the new Hebraists, who follow the rabbis altogether too strictly," and he included both Lyra and himself in the number of those who at one time or another had done so.71 Those who persist in such interpretation, he complained, are "saucy prigs who make bold to instruct the Holy Spirit."72 They "insist on imitating the Jews." ${ }^{173}$ Arguing for his interpretation of Exod 33:19, Luther staked out his ground over against both Jewish and Christian interpreters: "It is indifferent to me if rabbis or contentious Hebraists [die Rabinen oder zenckissche Ebreisten] do not accept this. ${ }^{.74}$ For Luther, the Trinity in the Old Testament had become the dividing line between him and not just the Jews, but the false Christian interpreters as well. "The devil," he fumed, "is their god and father, the father of all lies."

That bellicose assertion notwithstanding, Luther's tone in opposition to the Christian Hebraists was comparatively mild. This rhetorical posture suggests that Luther was serious about trying to turn the course of

67. WA 54: 28, 12; LW 15: 267.

68. WA 54: 46, 2; LW 15: 288. Burnett says that Sebastian Muenster figures prominently among the targets of Luther's criticism. According to Friedman, in the mid-1530s "reports of sabbatarianism in Austria and Moravia led Luther to believe that Jews were corrupting the new reformed church. Melanchthon and Calvin too expressed the same sentiments and fears." "Protestants, Jews, and Jewish Sources," 145.

69. WA 54: 30, 30-31; LW 15: 270.

70. WA 54: 29, 3-4; LW 15: 268.

71. WA 54: 30, 13-14, 26; LW 15: 268.

72. WA 54: 39, 6-7; LW 15: 280.

73. WA 54: 41, 37; LW 15: 283.

74. WA 54: 80, 20; LW 15: 329. Cf. his argument for his interpretation of Gen 4:1. WA 54: 73, 33: "Eben so musten auch alle ander Ebreisten bekennen, wenn sie denn text recht ansehen und hielten, das dieser Weibs samen Jehova, das ist Gott und Mensch were." Cf. LW 15: 321.

75. WA 54: 68, 32-33; LW 15: 315. Cf. the strong rhetorical posture in WA 54: 93, 23-25; LW 15: 344: "Therefore it behooves us to recover Scripture from them as from public thieves wherever grammar warrants this and harmonizes [reimet] with the New Testament." Emphasis mine. 
Christian Hebraism in a more Catholic direction. His anti-Jewish rhetoric thus functioned as an extreme that offered at least a measure of relief to Christian readers, presumably making it less psychologically difficult to repent their past errors and come over to Luther's way of thinking. ${ }^{76}$

\section{The Trinity in 2 Samuel 23}

As the Weimar editor, F. Cohrs, points out, Luther's dogmatic interest in 2 Sam 23 as a potential basis for defending Catholic teaching had been sharpened in part by continuing translation work carried out following the publication of the 1541 recension of the "Luther Bible" and in preparation for the 1545 edition, the last published during his lifetime."7 This interest took shape within a context where Luther had reached deep convictions regarding the Trinitarian and Christological significance of such texts as $1 \mathrm{Chr} 17: 7$ and Gen 4:1, as well as the royal psalms (particularly Ps 110). In these exegeses, as Helmer points out, the crucial factor was Luther's understanding of the semantic referent of the divine names, especially YHWH and Adonoi. ${ }^{78}$

Luther's study of Gen 4:1, for instance, had convinced him that Eve's words reported in the text referred clearly and directly to the promised Messiah. In itself, this was a new conclusion made possible only by a grammatical analysis of the Hebrew text. As recently as his own revision of the Vulgate text (published in 1529), Luther had chosen the genitive to translate the final crucial clause in the words spoken by Eve at the birth of Cain: "I have gotten the man Domini."79 In the 1545 recension of the Deutsche Bibel, Luther still translated this with the genitive; but he chose the accusative when he explained its proper meaning in the margin: "I have gotten the Man the Lord, the Seed" (Ich habe den Man den HERRN, den Samen). Moreover, in a lengthy examination of this text in "On the Last Words of David," Luther argued vehemently that the Hebrew article and noun that appears at the end of this sentence, "YHWH," should be translated not in the genitive but in the accusative. This locution, he claimed, should be understood as a clear indication that Eve believed she had given birth to the Messiah, "I have gotten the man, Jehovah." 80

76. For John Calvin's attempt to chart a via media here, see David L. Puckett, John Calvin's Exegesis of the Old Testament (Louisville, KY: Westminster John Knox Press, 1995).

77. WA 54: 18-19. For the publication history of the Luther Bible, see Siegfried Raeder, "Luther als Ausleger und Übersetzer der heiligen Schrift," in Leben und Werk Martin Luthers von 1526 bis 1546: Festgabe zu seinem 500. Geburtstag, ed. Helmar Junghans, 2 vols. (Göttingen: Vandenhoeck \& Ruprecht, 1983); here 1: 253-78.

78. "Luther's Trinitarian Hermeneutic," 56-59.

79. WADB 5: 16, 2.

80. WADB 8: 47. To be sure, Luther had long since reached this exegetical conclusion. Cf. WA 54: 71, 33; 73, 24; LW 15: 319, 321. 
That exegetical solution fit well into the general translational schema Luther had adopted as a solution to the problem of the divine names. ${ }^{81}$ It also aptly symbolizes the way Luther thought the new biblical studies could complement and deepen traditional Catholic readings of Scripture. Catholic expositors had long held that Gen 3 teaches that God promised victory over the serpent through the "seed of the woman," that is, the Messiah. ${ }^{82}$ Luther's intensification of that traditional exegetical conviction was to show how Eve and her husband had been enlivened by faith in that promise from the very beginning, even to the point of somewhat overoptimistically identifying their firstborn with the promised Messiah. The exegete can perceive this identification, according to Luther, in the Scripture's use of the accusative case with the term "YHWH" for "Lord" in Gen 4:1.

Similarly, Luther argued that the interpretive key to 2 Sam 23 consisted in the proper identification of the divine persons mentioned in verses 2 and 3: "the Spirit of the Lord," "The God of Israel," and "the Rock of Israel." 83 However, he did not base his Trinitarian interpretation of these names solely or even primarily on a grammatical analysis of the Hebrew text. To the contrary, he recognized that a reasonable interpreter shaped generically by any of what we today might call the "religions of Abraham" could miss this text's Trinitarian significance, quite naturally assuming that the terms "God" and "Rock" and "Ruler" refer "to God in one person in a superfluity of words. ${ }^{84}$ Against this admittedly more natural reading of the text, he argued that the Holy Spirit here introduces in the words "God" and "Rock" both the Father and the Son. The advance in Hebrew studies that Luther wanted to retain, in spite of the difficulties these studies admittedly caused, consisted in the grammatical analysis that showed that the diversity of divine names used here and elsewhere in the Hebrew text should not be understood as instances of a "superfluity of words" but as precious textual intimations-clear to the Christian-of the Triune God.

Although Luther offered some comparatively flimsy grammatical evidences to support his conclusions relative to 2 Sam 23, the decisive

81. In his German Bible, Luther translated the Hebrew Elohim with the German Gott; YHWH Elohim with Gott der HERR; YHWH with HERR; and Adonai with HErr.

82. For the history of interpretation of Gen 3:15, see Tibor Gallus, "Der Nachkomme der Frau" (Gen 3, 15) in der altlutheranischen Schriftauslegung (Klagenfurt: Carinthia, 1964).

83. WA 54: 35, 28-30; LW 15: 276 ff. Luther's text reads: "Es hat der Gott Israel zu mir gesprochen, Der Hort Israel hat geredt, der gerechte Herrscher unter den menschen, Der Herrscher in der furcht Gottes."

84. WA 54: 37, 6-7: "Und denckt nicht anders, es sey alles von Gott als von einer person geredt, mit vielen ubrigen worten." LW 15: 278. Cf. WA 54: 48, 28-30: "Hie stoesset sich nu fraw kluglinne, die Vernunft, die zehen mal Weiser is, denn Gott selbs, und fragt: Wie kan Gott seine Ewige Gewalt von sich einem andern geben?" The LW translator inexplicably renders "fraw kluglinne" with the masculine English "Mr. Smart Aleck," LW 15: 292. 
arguments were all theological and intertextual, including appeals to the New Testament. Thus, in the treatise itself Luther moved rather quickly from commentary on the text itself to analyses of other texts whose Trinitarian significance had already been somewhat better recognized. In his review of the biblical evidence for the Trinity and the two natures in Christ, Luther ranged widely across the testaments, from Isaiah, to Ps 2, Phil 2, 2 Sam 7, 1 Chr 17, John 1/Gen 1, Luke 3, Col 1-2, and Dan 7. In these texts, Luther found confirmation of his reading of 2 Sam 23. The point of the Scriptures as a whole-what others might have called the scopus Scripturae sacrae - thus provided the theological framework within which he carried out his analysis of the grammar of the text. "All points to the Son"; everything "is pure Christ." 85

As he worked his way through these texts, Luther commented at length on the subtle ins and outs of Catholic Trinitarianism, employing to good effect the conceptual tools developed in patristic and medieval tradition. In one rather lengthy section, for instance, he examined the question whether the "Our Father" is addressed to the person of the Father or to the divine essence itself. In answer, he invoked the same Trinitarian principle mentioned earlier by Denis. "The works of the Trinity to the outside are indivisible," he noted. Therefore, "the worship of the Trinity from the outside" is also the undivided worship of the one God. ${ }^{86}$ Divine paternity in relation to the creation, moreover, may be predicated not only of the Father, but also of the Son, of the Spirit, or even of the divine majesty as such. The "Our Father" is therefore addressed to the one God, both as to each of the divine persons and as to the undivided divinity itself. To put this in modern terms, Luther sees the creation as the result of the "common action" of the tripersonal God, even if it is rightly appropriated to the person of the Father. Luther's deft employment of the Trinitarian appropriations makes it clear once again that he utilized traditional methods of Trinitarian analysis, arrived at more or less traditional Trinitarian conclusions, and encouraged his readers to adopt them as well.

In addition, Luther laid down a general principle for Old Testament exegesis, insisting that wherever two of the divine persons are mentioned, "you may boldly assume that three Persons of the Godhead are there indicated." ${ }^{87}$ Proving himself consistent in the matter, in his interpretation of the texts examined in this treatise Luther consistently inserted the Spirit wherever he believed he could discern distinct references to the Father and the Son. Thus, for example, when the Father and the Son are spoken

85. WA 54: 88, 11-12; LW 15: 338-39.

86. WA 54: 65, 23-24; LW 15: 311. Luther cites the principle in Latin: "Quia opera trinitatis ad extra sunt indivisa, Sic cultus Trinitatis ab extra est indivisus." Emphasis mine.

87. WA 54: 39, 8-10: "Aber wo du in der schrifft findest, das Gott von Gott, als werens zwo Personen, redet. Da magstu kuenlich auff gruenden, das daselbs drey Personen in der Gottheit angezeigt werden." Cf. LW 15: 280. 
of without mention of the Spirit, the Spirit should be recognized as the speaker.88

Finally, it is crucial to note Luther's stance in relation to the antecedent exegetical tradition. He by no means intended to posture himself here as an exegetical innovator. While he could not cite the Church Fathers explicitly on 2 Sam 23, he nevertheless attempted to take them with him theologically, claiming kinship with their faith tradition and at the same time vindicating medieval Trinitarianism. The "dear fathers" (liebe Veter) he mentioned to support his case included Augustine, Anthony, Ambrose, Sedulius Scotus, Gregory I, Prudentius, Hilary, Cyril, and Athanasius. ${ }^{89}$ "We have precious books on this subject by St. Augustine, Hilary, and Cyril at our disposal," Luther wrote, adding that "this article of faith [i.e., the doctrine of the Trinity] remained pure in the papacy and among the scholastic theologians, and we have no quarrel with them on that score." However, even the witness of men of heroic faith could not serve as the foundation for Luther's Trinitarian reading of the Old Testament. Nor could the sheer authority of the church impose that reading, as it were, from outside the community of faithful readers-and still less from a position of authority over the word of God. ${ }^{91}$ Instead, the faith given in holy baptism, the faith by which alone the Trinitarian God is truly known, this faith enables the exegete rightly to perceive the mysteries inscribed in the verba of the holy text. The fathers, then, are "dear fathers" precisely because they read the Scriptures with that same faith, while scriptural exegesis remains a task given to the people of faith, that is, the church.

\section{CONCLUSION}

In the end, then, Luther's Trinitarian reading of the Old Testament as found in "On the Last Words of David" was grounded not in grammatical

88. See, e.g., WA 54: 39, 14-16 (LW 15: 280); WA 54: 46, 28-30 (LW 15: 289); WA 54: 48, 19-20 (LW 15: 291); WA 54: 53, 17-18 (LW 15: 297); etc.

89. WA 54: 56.4; LW 15: 300 .

90. WA 54: 64, 19-21: "Und ist solcher artickel im Papstum und bey den Schultheologen rein blieben, das wir mit inen darueber keinen zanck haben." Trans. LW 15: 310. Hilary, Augustine, and Cyril are commended for their treatment of John 1. For the continuities between Luther and the Western schoolmen on the Trinity, one may consult Kärkkäinen, Luthers trinitarische Theologie, as well as Knuuttila and Saarinen, "Innertrinitarische Theologie."

91. Luther criticized sixteenth-century Catholic Trinitarian exegesis of the Old Testament (particularly that of Johannes Eck) because Catholic exegetes defended Trinitarian theology not from Scripture, but on the basis of the teaching authority of the church. Luther saw excessive reliance on the church's authority in this matter as playing into the hands of such critics as Servetus, who had rejected the Trinity in part because, he claimed, the doctrine was not articulated until the fourth century. On this issue, see Helmer, "Luther's Trinitarian Hermeneutic," 51-52. 
or historical interpretation, but in a distinctive use of the regula fidei, that is, in the exegetical application of the faith which grasps and knows the Triune God, the very same faith Luther had sought to instill and encourage through his Large Catechism. This distinctive "rule of faith" consists not in an external list of theological truths on the basis of which one ought to interpret the Scriptures, but in the simultaneous realities of the God who is known and the act of faith in which God is known. This is the res that controls the understanding of the verba, for right interpretation depends in the first place on the right knowledge of the God revealed in the words of Scripture. ${ }^{92}$ Indeed, Luther spoke harshly of exegetes who could see the "letters" (Buchstabe) of the text but could not read "what they give" (was sie geben). These "illiterate," he complained, "cannot know or understand what Moses, the prophets, and the psalms are saying, what true faith is, what the Ten Commandments purport, what tradition and story [die Exempel und Historien] teach and prove."

At the same time, however, Luther wanted to put the best of the new scholarship to work in support of a robustly Christian reading of the Old Testament. The point of his argument, at least in so far as it was directed at Christian expositors, had to do with the fate and ultimate meaning of the emerging discipline of Hebrew studies for the understanding of the Christian Bible. Luther believed that the truth of Christian faith as known through word and sacrament was itself the key to rightly understanding the truth that could be found through the rapidly developing science of grammatical biblical exposition. Moreover, as James Samuel Preus pointed out long ago, Luther found in the Old Testament not merely a sub-Christian shadow, but the "faithful synagogue" where men of faith like the patriarch David truly knew and referred to the Triune God. ${ }^{94}$ Unlike some other sixteenth-century interpreters, then, Luther could never content himself to find and defend an irreducible minimum of clear and incontrovertible texts in support of central Christian claims. To the contrary, he wanted to show that the truth of the Nicene faith had been inscribed far and wide into every letter of Holy Scripture, and to insist that the explicit recognition of this truth should illuminate and inform every authentically Christian act of biblical interpretation.

The dynamic at work in the background of this treatise-the one that made necessary Luther's attempt to reinforce traditional Christian readings of the Old Testament-was what David Steinmetz has called the

92. For an interesting further example of Luther's invocation of this rule, one may consult Mattox, "Defender," 165-69.

93. WA 54: 30; LW 15: 269.

94. See Preus, From Shadow to Promise: Old Testament Interpretation from Augustine to the Young Luther (Cambridge: Harvard University Press, 1969). As Preus puts it, in Luther's thought, the faithful synagogue is "solidly in its own time, ante adventum, yet simul in spiritu" (174). 
"destabilizing effect" of humanist biblical study in the Reformation era on previously settled exegetical issues. "On the Last Words of David" reveals an elder Luther ill at ease in the rapidly shifting exegetical world he had helped to create. Indeed, it comes as something of a shock to see this accomplished biblical translator openly suggest that with the proliferation of faulty translations, the church would be better off with only Jerome's Vulgate-the position, it should be noted, adopted only two years later in the decree on Scripture at the Council of Trent. Nevertheless, Luther counseled not a retreat to the presumed securities of the old text, but the vigorous application of Christian faith to the problem of translating and interpreting the Scriptures anew. Therefore, we miss the point of his continuing appeal to Scripture "alone" as a theological court of last resort if we hear it as an appeal to the Scriptures as understood apart from the traditions of living Christian faith, or, for that matter, outside the mater ecclesia within which faith itself is imparted through word and sacrament. The knowledge of God given and received in the church is thus at the same time the foundation and the goal of any properly Christian reading of the Scriptures, the Old Testament together with the New. 